\title{
Wiesław Wenz
}

\section{Obowiązki duchownych w Kodeksie Kanonów Kościołów Wschodnich}

Prawo Kanoniczne : kwartalnik prawno-historyczny 45/3-4, 155-179

2002

Artykuł został zdigitalizowany i opracowany do udostępnienia w internecie przez Muzeum Historii Polski w ramach prac podejmowanych na rzecz zapewnienia otwartego, powszechnego i trwałego dostępu do polskiego dorobku naukowego i kulturalnego. Artykuł jest umieszczony w kolekcji cyfrowej bazhum.muzhp.pl, gromadzącej zawartość polskich czasopism humanistycznych i społecznych.

Tekst jest udostępniony do wykorzystania w ramach dozwolonego użytku. 
Prawo Kanoniczne

45 (2002) nr 3-4

KS. WIESŁAW WENZ

Papieski Wydzial Teologiczny we Wrocławiu

\section{OBOWIĄZKI DUCHOWNYCH W KODEKSIE KANONÓW KOŚCIOŁÓW WSCHODNICH}

\section{Wprowadzenie}

Kodeks Kanonów Kościołów Wschodnich (KKKW) został promulgowany przez Ojca Świętego Jana Pawła II dnia 18 października 1990 roku Konstytucją Apostolską Sacri Canones'. Zatem już dwunasty rok służy KKKW jako podstawowy zbiór norm prawa wspólnego dla wszystkich katolickich Kościołów Wschodnich, a więc pozostających w pełnej komunii ze Stolicą Apostolską. Wspomniany Kodeks różni się od Kodeksu Prawa Kanonicznego Kościoła Łacińskiego układem prezentowanych treści. Nie zastosowano podziału na księgi lecz zachowano w zbiorze podział na XXX tytułów, obejmujących normy istotne dla tożsamości wspólnot Katolickich Kościołów Wschodnich ${ }^{2}$. Interesujące nas normy kodeksowe dotyczące

' Por. Jan Paweł II, Konstytucja Apostolska Sacri Canones z dnia 18 X 1990 roku, w: Kodeks Kanonów Kościołów Wschodnich promulgowany przez Papieża Jana Pawła II, Lublin 2002, s. 29-41.

2 Poszczególne tytuly KKKW: I - Chrześcijanie, ich wszystkie prawa i obowiązki (kan. 7-26); II - Kościoły sui iuris i obrządki (27-41); III - Najwyższa władza Kościoła (42-51); IV - Kościoły patriarchalne (55-150); V - Kościoły arcybiskupie większe (151-154); VI Kościoły metropolitalne i pozostałe Kościoły sui iuris (155-176); VII - Eparchie i biskupi (177-310); VIII - Egzarchaty i egzarchowie (311-321); IX - Zgromadzenia hierarchów wielu Kościolów sui iuris (322); X - Duchowni (323-398); XI - Świeccy (399-409); XII - Mnisi i inni zakonnicy oraz czlonkowie innych instytutów życia konsekrowanego (410-572); XIII - Stowarzyszenia chrześcijan (573-583); XIV - Ewangelizacja narodów (584-594); XV - Magisterium Kościola (595-666); XVI - Kult Boży, zwłaszcza sakramenty (667-985); XVII - Ochrzczeni akatolicy przystępujący do pełnej wspólnoty z Kościolem katolickim (896-901); XVIII - Ekumenizm czyli wspieranie jedności chrześcijan (902-908); XIX - Osoby i akty prawne (909-935); XX - Urzędy (936-978); XXI - Władza rządzenia (979-995); XXII - Rekursy przeciwko dekretom administracyjnym 
obowiązków duchownych znajdują się zatem w tytule $\mathrm{X}$ i rozdziale III wspomnianego zbioru prawa powszechnego KKKW, a mianowicie w kanonach 367-393. Podstawowym celem niniejszego opracowania jest prezentacja norm szczegółowych, jak również dokonanie porównania promulgowanych dla Katolickich Kościołów Wschodnich norm $z$ obowiązującym w Kościele Łacińskim Kodeksem Prawa Kanonicznego, a zwłaszcza z kanonami 273-2893. Już pobieżna lektura wspomnianych Kodeksów pozwala ustalić, iż w tym zakresie charyzmatyczna tożsamość obu zbiorów norm prawnych jest zbieżna na wielu płaszczyznach. Dlatego Kościół przypomina duchownym obu obrządków o ich obowiązkach zarówno względem Ludu Bożego, jak również wobec siebie, aby każdy z nich mógł ukształtować w sobie prawdziwy duchowy charakter. Jego istotą powinna być pełna miłości i pilności postawa duchownego względem tajemnic Bożych, uformowana na mocnym fundamencie prawdziwych cnót życia chrześcijańskiego ${ }^{4}$.

\section{Obowiązki duchownych Kościołów Wschodnich}

Odnosząc się do obligatoryjnie wymienionych w KKKW obowiązków wspólnych wszystkim duchownym Katolickich Kościołów Wschodnich powinniśmy zachować w pamięci również te powinności, jakie przysługują duchownym $\mathrm{z}$ racji ich podstawowej, a więc chrzcielnej przynależności do Ludu Bożego, tak by w niczym nie uchybić zasadom wynikającym z prawa naturalnego, prawa Bożego i prawa kościelnego ${ }^{5}$. Okoliczności te zobowiązują również do dokładnego poznania i świadomego chronienia praw każdego wiernego, także praw osoby duchownej, która $z$ racji godności ludzkiej i sakramentu Chrztu św. zawsze winna wewnętrznie identyfikować się ze wszystkimi prawami członków Ludu Bożego, zanim pocznie korzystać z przysługujących jej praw i realizować obowiązki, odno-

(996-1006); XXIII - Dobra doczesne Kościola (1007-1054); XXIV - Sądownictwo w ogólności (1055-1184); XXV - Proces sporny (1185-1356); XXVI - Niektóre procesy specjalne (1357-1400); XXVII - Sankcje karne w Kościele (1401-1467); XXVIII - Procedura przy wymierzaniu kar (1468-1487); XXIX - Ustawa, zwyczaj, akty administracyjne (1488-1539); XXX - Przedawnienie i obliczanie czasu (1540-1546).

${ }^{3}$ Por. Kodeks Prawa Kanonicznego (cyt. dalej = KPK), Przeklad polski zatwierdzony przez Konferencję Episkopatu Polski, Pallottinum 1984, kan. 273-289.

4 Por. Віктор Д. Поспішіл, Східне Католицьке Церковне право. Згідно з Кодексом Канонів Східних Церков, Львів 1997, s. 185.

${ }^{5}$ Por. G. Ghirlanda, Wprowadzenie do prawa kościelnego, Kraków 1996, s. 79. 
szące się do aktualnie sprawowanej funkcji czy urzędu kościelnego. Taki program działania jest obowiązujący, bowiem prawodawca kościelny autorytatywnie potwierdził prawdziwą równość w godności i działaniu pomiędzy wszystkimi wiernymi ${ }^{6}$, jak również nierówność pomiędzy nimi samymi, ponieważ w osobowym życiu każdy aktualizuje swoje powolanie, które Chrystus powierzył Kościołowi do wypełnienia na świecie w sposób jemu właściwy, według własnego stanu prawnego i własnych zadań?. Tak więc, płaszczyzną równości pomiędzy wszystkimi wiernymi jest wcielenie do Kościoła i wejście w „posiadanie” praw i obowiązków właściwie przynależnych każdej osobie (chrześcijaninowi) ${ }^{8}$, zaś zasygnalizowana wyżej nierówność opiera się na uprawnieniach wynikających $\mathrm{z}$ różnych funkcji i posług opisanych przez różnorodność charyzmatów, które każdy może odkryć w sobie i rozwinąć je w Kościele w obrębie niepowtarzalności swego powołania, jednakże ze świadomością, by chronić wspólnotę Kościoła przed rozbiciem i wspierać innych w godnym korzystaniu z ich uprawnień, jak również w odpowiedzialnej realizacji istotnych obowiązków9.

Podstawowym źródlem obowiązków i praw wiernych świeckich może być ich faktyczna przynależność do wspólnoty Ludu Bożego ${ }^{10}$, udział w potrójnej misji Chrystusa (nauczania - uświęcania - pasterzowania) ${ }^{11}$ i wypełnianie szczególnego powołania kapłańskiego ${ }^{12}$. Natomiast głównym źródlem obowiązków i praw dla duchownych

- Źródłem takiego stanu rzeczy jest chrzcielna tajemnica wcielenia w Chrystusa i ukonstytuowanie w Lud Boży, a przez to bezpośrednie uczestnictwo w Chrystusowej misji kapłańskiej, prorockiej i królewskiej. Por. Kan. 204 \$ 1, 208 KPK.

${ }_{7}^{7}$ Por. Jan Pawel II, Adhortacja Apostolska Christifideles laici z dnia 30 grudnia 1988 roku, nr 17, w: Adhortacje Ojca Świętego Jana Pawła II, t. I, Kraków 1996, s. 293.

${ }^{8}$ Por. Kan. 96 KPK.

9 „Zadaniem własnym prawa kościelnego jest właśnie to, by wierni przezwyciężali wlasny indywidualizm i urzeczywistniali swoje powołanie, zarówno osobiste jak i wspólnotowe, ponieważ cel prawa w Kościele jest dwojaki: chronić wspólnotę kościelną i wspierać prawa poszczególnych wiernych". G. Ghirlanda, Wprowadzenie do prawa kościelnego, s. 84.

${ }^{10}$ Por. J. Dyduch, Obowiazki i prawa wiernych świeckich w prawodawstwie soborowym, Kraków 1985, s. 74-119.

"Por. Sobór Watykański II, Dekret o apostolstwie świeckich „Apostolicam actuositatem”, nr 2; Konstytucja dogmatyczna o Kościele „Lumen gentium”, nr 31; Por. Instrukcja o niektórych kwestiach dotyczacych wspótpracy wiernych świeckich $w$ ministerialnej postudze kaptanow, w: LOsservatore Romano, wyd. polskie, 12 (208) 1998, s. 30-40.

${ }_{12}$ Por. J. Dyduch, Obowiazki i prawa wiemych świeckich w prawodawstwie soborowym, s. 179-211. 
obu obrządków staje się ich bezpośredni udział w misterium kapłaństwa Jezusa Chrystusa, od chwili przyjęcia święceń kapłańskich w stopniu diakona i prezbitera ${ }^{13}$. Chociaż nazwa rozdziału III tytułu $\mathrm{X}$ KKKW została ustalona jako prawa i obowiazki duchownych, to jednak tekst prezentowanych szczególowych norm kodeksowych dotyczy najpierw obowiązków osób duchownych. Stąd również w tym opracowaniu zostanie uszanowana kodeksowa systematyka.

\section{Obowiązek gloszenia Królestwa Bożego}

Pierwszym obowiązkiem duchownego jest głoszenie wszystkim Królestwa Bożego oraz miłości Boga do ludzi w posłudze słowa i sakramentów świętych. Duchowny powinien zatem celowo w swoim ministerialnym posługiwaniu ukazywać miłość Boga względem człowieka, jak również integralnie włączyć w to dzieło swoje osobiste życie i postępowanie, aby potęgować wzajemną miłość Ludu Bożego, której źródłem jest miłość Boga. Prawodawca wskazał, aby przeżywanie tajemnicy miłości posiadało charakter apostolsko-misyjnej działalności, która stale powinna prowadzić wiernych do budowania Ciata Chrystusa i osobistego wzajemnego wzrastania ${ }^{14}$. Ten pierwszy kodeksowy obowiązek duchownych Katolickich Kościołów Wschodnich ma swoje źródło w soborowej nauce Kościoła, która postrzega prezbiterów jako dtużników wszystkich mających się „dzielić z nimi prawdą Ewangelii”, nauczając głosić również „niewierzącym tajemnicę Chrystusa”, „uczyć nie swojej mądrości, lecz słowa Bożego, usilnie zachęcając wszystkich do nawrócenia i świętości"1s. Tak więc życie duchownego i trud przepowiadania Słowa Bożego powinno mieć charakter świadectwa ewangelicznego, dokonującego się często w trudnych okolicznościach świata, po-

${ }^{13}$ Por. Kan. $266 \S 1 \mathrm{KPK}$; „Na mocy ustanowienia Bożego /... / są oni mianowicie konsekrowani i przeznaczeni ażeby - każdy odpowiednio do swojego stopnia, wypełniając w osobie Chrystusa - Glowy zadania nauczania, uświęcania i kierowania - byli pasterzami Ludu Bożego". Kan. 1008 KPK.

".Clerici primam habent obligationem Regnum Dei omnibus annuntiandi et amorem Dei erga homines in ministerio verbi et sacramentorum, immo et tota vita repraesentandi ita, ut omnes invicem et super omnia Deum diligentes in Corpus Christi, quod est Ecclesia, aedificentur atque crescant". Kan. $367 \mathrm{KKKW}$; Por. Віктор Д. Поспішіл, Східне Католичьке Церковне право. Зеідно з Кодексом Канонів Східних Церков, s. 185.

${ }_{15}$ Por. Sobór Watykański II, Dekret o posłudze i życiu kaplanów Presbyterorum ordinis $\mathrm{z}$ dnia 7 grudnia 1965 r., nr 4; Por. Kan. 367 KKKW. 
ruszającego umysły i serca słuchaczy, integralnie aplikującego prawdę Ewangelii do konkretnych warunków życia. Prawodawcy zależy bowiem, aby codzienne życie i działanie duchownych było postrzegane w wymiarze świadectwa żywej i autentycznej wiary ${ }^{16}$.

\section{Obowiązek dążenia do doskonalości Chrystusowej}

Prawodawca postanowił, iż na wszystkich duchownych Katolickich Kościołów Wschodnich spoczywa także szczególny sposób realizowania obowiązku dążenia do doskonałości, nakazanej przez Jezusa Chrystusa swoim uczniom. Motywem do permanentnego spełniania tego obowiązku jest fakt, iż duchowni przez święcenia zostali w nowy sposób poświęceni Bogu, aby stawali się bardziej zdatnymi narzędziami Chrystusa wiecznego Kaplana w służbie ludowi Bożemu oraz by równocześnie byli przykładem dla świata ${ }^{17}$.

Należy zauważyć, iż powyższy obowiązek jest wspólny z obowiązkiem duchownych Kościoła Łacińskiego, których prawodawca zobowiązuje też do dążenia do doskonałości i świętości. Podstawowym motywem inspirującym prawodawcę do wyznaczenia duchownym obrządków katolickich takiego obowiązku jest fakt ich wewnętrznej konsekracji, dokonującej się w akcie przyjętych święceń oraz to, że przez święcenia zostali ustanowieni szafarzami Bożych tajemnic dla służenia Ludowi Bożemu. Jest to szczególna, lecz druga racja obligująca każdego duchownego do troski o zdobycie osobistej świętości ${ }^{18}$, ponieważ motywacja pierwsza wynika $z$ fundamentalnej racji, a mianowicie przynależności do Ludu Bożego ${ }^{19}$, z którym są wspólnie powołani do ewangelicznej doskonałości.

Kodeks Kanonów Kościołów Wschodnich jak również prawo kodeksowe Kościoła Łacińskiego wylicza obligatoryjnie okoliczności, które stwarzają najbardziej optymalne warunki osiągnięcia kapłańskiej doskonałości. Dlatego duchowni powinni codziennie oddawać się czytaniu i rozważaniu Słowa Bożego, być gorliwym w modlitwie, sprawowaniu liturgii, zwłaszcza w celebracji kultu i tajemnicy Eucharystii, w czynieniu rachunku sumienia, przystępowaniu do sakramen-

\footnotetext{
${ }^{16}$ Por. Sobór Watykański II, Dekret o posłudze i życiu kapłanów Presbyteronum ordinis, $\mathrm{nr} 4$.

${ }^{17}$ Por. Kan. 368 KKKW.

${ }^{18}$ Por. Kan. $276 \$ 1$ KPK.

19 Por. Kan. 217 KPK; Por. R. C. Martin, Powolani do świętości. Co znaczy spotkać Boga Żywego, Wroclaw-Kraków 1993, s. 29-33.
} 
tu pokuty, oddawaniu czci Przenajświętszej Maryi Bogurodzicy, spełnianiu innych obrzędów własnego Kościoła sui iuris, cenieniu kierownictwa duchowego, odprawianiu ćwiczeń duchowych, zgodnie $\mathrm{z}$ przepisami prawa partykularnego ${ }^{20}$. Zdaniem prawodawcy duchowni powinni w tym celu wiernie i niestrudzenie wypełniać obowiązki pasterskiej posługi ${ }^{21}$, jak również w Kościele Łacińskim powinni swoje życie duchowe karmić mocą Pisma Swiętego i codziennie sprawowanej Eucharystii ${ }^{22}$. Powinni także zdobywać swą doskonałość realizując codzienny obowiązek odmawiania godzin brewiarzowych $^{23}$, odprawiając rekolekcje, zgodnie $\mathrm{z}$ zaleceniami prawa partykularnego ${ }^{24}$, jak również podejmując praktykowanie powszechnie lub lokalnie przyjętych środków uświęcających życie kapłańskie, m.in. regularnie oddawali się rozmyślaniu, często przystępowali do sakramentu pokuty i mieli szczególne nabożeństwo do Matki Bożej2s. Kodeks Kanonów Kościołów Wschodnich wszystkich swoich duchownych zobowiązal do sprawowania Liturgii Godzin zgodnie z prawem partykularnym własnego Kościoła sui iuris ${ }^{26}$. Ten obowiązek integralnie wpisany w trud zdobywania doskonałości Chrystusowej dotyczy tzw. czytania czasostowas, obowiązującego w różnym stopniu w niektórych wschodnich wspólnotach katolickich, wprowadzonego pod wpływem Kościoła Łacińskiego ${ }^{27}$.

${ }^{20}$ "Clerici in lectionem et meditationem verbi Dei cottidie incumbant ita, ut Christi auditores fideles atque attenti facti evadant veraces ministri praedicationis; in oratione, in celebrationibus liturgicis et praesertim in devotione erga mysterium Eucharistiae assidui sint; conscientiam suam cottidie discutiant et sacramentum paenitentiae frequenter suscipiant; Sanctam Mariam semper Virginem, Dei Matrem colant et ab ea gratiam se conformandi eius Filio implorent aliaque propriae Ecclesiae sui iuris exercitia pietatis peragant". Kan. $369 \S 1-2$ KKKW; Por. Sobór Watykański II, Konstytucja dogmatyczna o Kościele „Lumen gentium”, nr 41; Sobór Watykański II, Dekret o posłudze i życiu kaplanów Presbyterorum ordinis, nr 12-14; Рог. Віктор Д. Поспішіл, Східне Католичьке Церковне право. Згідно з Кодексом Канонів Східних Церков, s. 185.

${ }^{2 !}$ Kan. 276 \& 2,1 KPK.

${ }^{22}$ Kodeks zachęca diakonów, by uczestniczyli w codziennie sprawowanej Ofierze eucharystycznej. Por. Tamże, $\$ 2,2$.

${ }^{23} \mathrm{~W}$ tym obowiązku uczestniczą również diakoni stali, którzy odmawiają godziny brewiarzowe zgodnie z dyrektywami Konferencji Episkopatu. Por. Tamże, \$ 2,3.

${ }^{24}$ Por. Tamze, $\$ 2,4$.

${ }^{25}$ Por. Tamże, § 2,5; Por. Sobór Watykański II, Dekret o posludze i życiu kaplanów Presbyterorum ordinis, $\mathrm{nr} 18$.

${ }^{26}$ Por. Kan. 377 KKKW.

${ }^{27}$ Рог. Віктор Д. ПТоспішіл, Східне Католичьке Церковне право. Зеідно з Кодексом Канонів Схіних Церков, s. 186. 
Wydaje się, że integralną częścią obowiązku zdobywania doskonałości Chrystusowej staje się dla duchownego częste sprawowanie Boskiej Liturgii, zwłaszcza w niedziele i święta nakazane, zgodnie $\mathrm{z}$ przepisami prawa partykularnego Katolickich Kościołów Wschodnich. Prawodawca gorliwie polecil duchownym nawet codzienne sprawowanie Boskiej Liturgii ${ }^{28}$. Należy wyjaśnić w tym miejscu, że często słyszy się, iż codzienne odprawianie liturgii Najświętszej Eucharystii jest wyłącznie charakterystyczne dla praktyki Kościola Łacińskiego ${ }^{29}$. W piśmiennictwie chrześcijańskim znajdują się jednak wyraźne świadectwa, że codzienną Służbę Bożą praktykowano również w pierwotnym Kościele Wschodnim, m.in. przez św. Bazylego Wielkiego. Przed połączeniem ze Stolicą Rzymską, katolicy wschodni sprawowali w dni powszednie nabożeństwa nieeucharystyczne, zwłaszcza za wiernych zmarłych (co w tradycji bizantyjsko-słowiańskiej nazywano: panichida, parastas), a także modlitewne nabożeństwa w różnych intencjach (moleben oraz akatyst). Ta wschodnia tradycja często pozostawała niezauważona ze względu na praktykę codziennej liturgii Najświętszej Eucharystii w Kościele Łacińskim ${ }^{30}$.

\section{Obowiązek okazywania szacunku i posłuszeństwa}

Nie tylko duchowni w Kościele Łacińskim mają szczególny obowiązek okazywania szacunku i posłuszeństwa Ojcu Świętemu oraz własnemu ordynariuszowi ${ }^{3 !}$. Podobną normę ustalił prawodawca w KKKW dla duchownych Katolickich Kościołów Wschodnich, obligatoryjnie wzywając do szczególnego okazywania szacunku oraz posłuszeństwa Biskupowi Rzymskiemu, Patriarsze i Biskupowi eparchialnemu ${ }^{32}$. Ojciec Święty jest bowiem widzialną Głową całego Kościoła, razem ze wszystkimi biskupami kieruje życiem Ludu Bożego, a duchowni wszystkich obrządków katolickich, pomagając im w nauczaniu, uświęcaniu i kierowaniu wspólnotą są ich współpracownikami. Postawa posłuszeństwa i szacunku duchownych wo-

\footnotetext{
${ }^{28}$ Por. Kan. $378 \mathrm{KKKW}$.

29 Por. Kan. $276 \S 2$ n. 2 KPK.

${ }^{30}$ Рог. Віктор Д. Поспішіл, Східне Католичьке Церковне право. Заідно з Кодексом Канонів Східних Церков, s. 186.

${ }^{31}$ Por. Kan. 273 KPK.

${ }^{32}$ „Clerici speciali obligatione tenentur Romano Pontifici, Patriarchae et Episcopo eparchiali reverentiam et obaedientiam exhibendi”. Kan. 370 KKKW.
} 
bec Papieża i biskupów powinna być przepojona duchem i wolą ofiarnej współpracy. Duchowni od swego ordynariusza otrzymują misję kanoniczną ${ }^{33}$ a w liturgii przyjęcia święceń składają ordynariuszowi uroczystą obietnicę okazywania szacunku i czci oraz posłuszeństwa ${ }^{34}$. Należy przypomnieć, że okazywanie przełożonym szacunku polega zazwyczaj na oddaniu im honoru, czci i poważania w podejmowanej codziennej współpracy, zwłaszcza przez budowanie pełniejszej jedności braterskiej w Chrystusie. Natomiast postawa posłuszeństwa kanonicznego zobowiązuje duchownych do wykonywania poleceń ordynariusza, wydanych zgodnie $z$ zakresem jego władzy. Dlatego - zgodnie z dyscypliną Kościoła - w sprawy osobiste i prywatne duchownych, które nie są integralnie związane z obowiązkami stanu, ordynariusz może ingerować tylko wówczas, gdy one są przeciwne wierze i chrześcijańskiej moralności, jak również ilekroć duchowny przez swoją postawę narusza publiczne dobro Kościoła ${ }^{35}$. Postawa autentycznego posłuszeństwa motywowana jest miłością oraz zobowiązuje nie do sprzeciwu i buntu, lecz do roztropnego poszukiwania nowych dróg pasterzowania. Stąd zachęta soborowa, aby duchowni odważnie występowali $z$ inicjatywą i jasno przedkladali potrzeby trzody sobie powierzonej ${ }^{36}$. Pełniejsza realizacja obowiązku okazywania szacunku i posłuszeństwa służy zacieśnieniu braterskiej jedności kapłańskiej w Chrystusie.

\section{Obowiązek przyjęcia urzędu - posługi - zadania}

Prawodawca w KKKW postanowił również, że duchowni Katolickich Kościołów Wschodnich mają obowiązek przyjąć i wiernie wypełnić wszelki urząd, posługę lub zadanie powierzone im przez kompetentną władzę, ilekroć według osądu tejże władzy wymaga

${ }^{33}$ Por. Sobór Watykański II, Dekret o posłudze i życiu kapłanów Presbyterorum ordinis z dnia 7 grudnia 1965 r., nr 7; „Posługa kapłańska jest posługą samego Kościoła, nie może być wypełniona inaczej jak tylko we wspólnocie hierarchicznej całego ciała. Tam$\dot{z e}, \mathrm{nr} 15$.

${ }^{34}$ Każdy kandydat na pytanie postawione przez biskupa udzielającego święceń: „Czy przyrzekasz swojemu ordynariuszowi cześć i posłuszeństwo?” odpowiada: „Przyrzekam”.

${ }^{35} \mathrm{~W}$ takiej sytuacji zawsze winni się poddać decyzji i zdaniu tych, którzy wykonują naczelne zadanie w kierowaniu Kościolem. Por. Sobór Watykański II, Dekret o posłudze i życiu kaplanów Presbyterorum ordinis, nr 15; Por. T. Pawluk, Prawo kanoniczne wedlug Kodeksu Jana Pawla II, t. IV, Olsztyn 1990, s. 84.

${ }^{36}$ Por. Sobór Watykański II, Dekret o posłudze i życiu kapłanów Presbyteronum ordinis, nr 7 i 15. 
tego konieczność Kościoła ${ }^{37}$. Niemal identyczna norma znajduje się Kodeksie Prawa Kanonicznego Kościoła Łacińskiego ${ }^{38}$. Wydaje się więc, że jedynie słusznym wytłumaczeniem duchownego od nie przyjęcia powierzonego mu urzędu - posługi - zadania może być zaistnienie prawnie uznanej przeszkody, np. choroby, podeszlego wieku, czy też wykonywania już innej posługi kanonicznej. Zgodnie $z$ przyjętą procedurą prawną zainteresowany duchowny powinien o zaistnieniu przeszkody poinformować swego ordynariusza, który osobiście podejmuje decyzję, czy przedstawione motywy odmowy przyjęcia urzędu kościelnego są wystarczające. Może zdarzyć się i tak, że duchowny będzie opornym w realizacji tego obowiązku, a więc w jego przyjęciu. Wówczas ordynariusz, jeśli upomnienie nie przyniesie oczekiwanego rezultatu, może duchownego ukarać39. Tak więc duchowni we wszystkich obrządkach Kościoła Katolickiego mają obowiązek przyjęcia i wypełnienia od swojego ordynariusza stałego lub przejściowego tzw. zadania kościelnego. Powinność ta wynika $z$ obowiązku okazywania swemu przełozonemu kanonicznego posłuszeństwa ${ }^{40}$ oraz z zasady sprawiedliwości, ponieważ duchowny został wyświęcony nie dla własnego dobra i dla własnych spraw, lecz dla posługiwania kapłańskiego w diecezji i dla duchowego dobra wiernych.

W KKKW znajduje się również norma dotycząca możliwości wypełniania przez duchownych Katolickich Kościołów Wschodnich zawodu świeckiego. Może się to jednak dokonywać wylącznie po uzyskaniu zgody od własnego Hierarchy ${ }^{41}$. Obecnie zatrudnianie duchownych w zawodach cywilnych, zwłaszcza w Kościołach Wschodnich ze względu na liczebnie małe wspólnoty, w wielu krajach jest konieczne dla zabezpieczenia minimum życiowego. Wskazuje się

\footnotetext{
${ }^{37}$ „Suscipiendum est clericis ac fideliter implendum omne officium, ministerium vel munus ab auctoritate competenti eis commissum, quandocumque id de eiusdem auctoritatis iudicio necessitates Ecclesiae exigunt”. Kan. 371 \& $2 \mathrm{KKKW}$.

${ }^{36}$ Por. Kan. 274 § 2 KPK.

${ }^{39}$ „Powinien być sprawiedliwie ukarany: $2 *$ kto w inny sposób okazuje nieposłuszeństwo Stolicy Apostolskiej, ordynariuszowi lub przełożonemu, który zgodnie z prawem coś nakazują lub czegoś zakazują, i po upomnieniu trwa w nieposłuszeństwie". Kan. 1371, 2 KPK.

${ }^{40}$ Por. Kan. 273 KPK; Por. Sobór Watykański II, Dekret o posłudze i życiu kaplanów Presbyterorum ordinis, nr 15.

" "Ut vero professionem civilem exercere possint, requiritur licentia proprii Hierarchae". Kan. 371 § 3 KKKW.
} 
obecnie na możliwości podjęcia przez duchownych pracy w niepełnym wymiarze godzin roboczych, zwłaszcza jako nauczających w szkołach katolickich ${ }^{42}$, aby zabezpieczyć sobie środki konieczne do materialnego utrzymania, bowiem środki ofiarowane przez małą i ubogą wspólnotę eklezjalną często są niewystarczające.

\section{Obowiązek stałej formacji intelektualnej i pastoralnej}

Prawodawca w tej kwestii postanowil, że duchowni po zakończeniu kształcenia w świętych naukach, wymaganego do przyjęcia święceń, nie powinni rezygnować $z$ procesu teologicznego kształcenia. Powinni natomiast pogłębiać dotychczas zdobytą wiedzę, dostosować ją do współczesnych wymagań, korzystając w tym celu z kursów formacyjnych zaaprobowanych przez własnego Hierarchę ${ }^{43}$. Duchowni powinni też uczestniczyć w spotkaniach formacyjnych, które własny Hierarcha uzna za potrzebne do rozwijania świętej nauki i pastoralnych metod ${ }^{44}$. Nie powinni również zaniedbywać formacji intelektualnej z zakresu wiedzy świeckiej, zwłaszcza tych dyscyplin, które ściślej łączą się z nauką teologiczną, aby ich formacja intelektualna w tym zakresie nie była mniejsza niz lu$d z i$ wyksztatconych ${ }^{45}$. W powyższych normach kodeksowych została zawarta pełna troska prawodawcy o solidną formację intelektualną, teologiczną i pastoralną wszystkich duchownych obrządków katolickich.

Obowiązek ten należy postrzegać pozytywnie, bowiem nieustanne kształcenie i doskonalenie warsztatu teoretycznego jest powinnością i stawianym wymogiem wobec osób uprawiających wiele dyscyplin. Dlatego duchowni - również w Kościele Łacińskim - nawet po przyjęciu sakramentu święceń są obowiązani kontynuować

\footnotetext{
${ }^{42}$ Por. Віктор Д. Поспішіл, Східне Католичьке Церковне право. Згідно з Кодексом Канонів Схіних Церков, s. 185-186.

43 "Institutione, quae ad ordines sacros requiritur, peracta in scientias sacras incumbere ne desinant clerici, immo profundiorem et ad diem accommodatam earundem cognitionem et usum acquirere satagant per cursus formativos a proprio Hierarcha approbatos”. Kan. $372 \S 1 \mathrm{KKKW}$; Por. Sobór Watykański II, Dekret o formacji kaplańskiej Optatam totius, nr 22.

${ }_{44}$ "Frequentent quoque collationes, quas Hierarcha opportunas iudicavit ad scientias et res pastorales promovendas". Kan. 372 \& 2 KKKW; Por. Can. 131§ 1,3 CIC/1917; Por. Paulus VI, Motu proprio Ecclesiae sanctae, nr 7.

${ }^{45}$ Por. Sobór Watykański II, Dekret o posłudze i życiu kaplanów Presbyterorum ordinis, nr 19; Por. Kan. 372 § 3 KKKW.
} 
studia teologiczne, by przygotować się do podjęcia korzystniejszego dialogu ze współczesnym światem ${ }^{46}$. Winni nieustannie czerpać z solidnej doktryny teologicznej, opartej na Objawieniu, przekazanej przez tradycję poprzednich pokoleń ludzi Kościoła, określonej w oficjalnych dokumentach Soborów i nauce papieży. Duchowni powinni unikać świeckich nowości oraz fałszywej wiedzy ${ }^{47}$. Przepisy prawa partykularnego powinny określić szczegółowe obowiązki duchownych związane $\mathrm{z}$ dalszą formacją intelektualną, a zwłaszcza uczęszczanie na wykłady duszpasterskie, udział w zebraniach teologicznych i konferencjach, które winny stać się dobrą okazją do pełniejszego poznania wspólczesnej teologii i aktualnych metod duszpasterskich w Kościele ${ }^{48}$. Kapłani mają także obowiązek poznawania innych dyscyplin naukowych, zwłaszcza tych, które integralnie są związane $\mathrm{z}$ ich rodzajem pracy w Kościele ${ }^{49}$. Tak więc prawodawca w KKKW i KPK zawart istotne normy obligujące duchownych do troski o osobistą permanentną formację intelektualną i pastoralną, aby jak najgodniej i najowocniej pełnić swoje posługiwanie zbawcze w wymiarze biblijnego świadectwa. Potrzebna jest zatem stała formacja, aby duchowni byli dojrzali $w$ wiedzy $i$ aby ich nauka byla duchowym lekarstwem dla Ludu Bożego, zaś ich wiedza powinna być święta, „,bo wzięta ze świętego źródła” i skierowana również do osiągnięcia świętego celu ${ }^{50}$.

\section{Obowiązek świętego posługiwania w jedności}

Prawodawca obligatoryjnie stwierdził, iż wszyscy duchowni przez kapłańskie posługiwanie uczestniczą w budowaniu jedności Ciała Chrystusowego. Ten jedyny cel powinni realizować na płaszczyźnie miłości ze wszystkimi współbraćmi jakiegoś Kościoła sui iuris. Dlatego zostali zobligowani są do nawiązania we wspólnocie Kościoła godnych relacji z innymi duchownymi, bez względu na zajmowaną

\footnotetext{
${ }^{4}$ Por. Sobór Watykański II, Dekret o posłudze i życiu kapłanów Presbyterorum ordinis, nr 19.

${ }^{47}$ Por. Kan. 279 § 1 KPK.

${ }^{48}$ Por. Kan. 279 \& 2 KPK.

${ }^{49}$ Do takich dziedzin należeć będzie psychologia, psychiatria, socjologia, pedagogika, które mają bezpośredni związek $z$ duszpasterstwem specjalistycznym lub pracą np. w sądownictwie kościelnym. Wspomniane dziedziny na pewno ulatwiają wykonywanie pasterskiej posługi. Por. Kan. 279 \& 3 KPK.

${ }^{50}$ Por. Sobór Watykański II, Dekret o posłudze i życiu kapłanów Presbyteronum ordinis, nr 19.
} 
jakąkolwiek pozycję i spełnianie różnorodnych funkcji w swoim Kościele. Między nimi istnieje kanoniczny obowiązek współpracy i świadczenia sobie wzajemnie pomocy ${ }^{51}$. Jest to wystarczający motyw do zaistnienia między duchownymi węzła solidarnego braterstwa i modlitwy oraz autentycznej współpracy, z zachowaniem wskazań przepisów prawa partykularnego ${ }^{52}$. Przepisy szczegółowe w materii obowiązku świętego posługiwania w jedności, zarówno w KKKW i KPK, odzwierciedlają ducha wskazań Soboru Watykańskiego II, na którym apelowano o solidarność kapłańską i godną współpracę, by wszyscy prezbiterzy, tak diecezjalni jak $i$ zakonni, wzajemnie się wspomagali, aby być zawsze wspótpracownikami prawdy ${ }^{53}$. W okresie formacyjnym należy zatem zwrócić uwagę kandydatom do kapłaństwa, by później chcieli budować jedność z prezbiterami starszymi, szanując ich wiek i doświadczenie oraz radząc się ich w sprawach dotyczących duszpasterstwa ${ }^{54}$. Tak więc autentyczna współpraca pomiędzy duchownymi różnych Kościolów sui iuris winna rozwijać się i umacniać, ponieważ zawsze staje się przykładem braterskiej miłości.

\section{Obowiązek troski o powolania kaplańskie i zakonne}

$\mathrm{Na}$ wszystkich duchownych prawodawca nałożył obowiązek wspierania dzieła powołań do świętej służby i do życia w instytutach życia konsekrowanego. Sprawę powołań należy popierać wszystkimi możliwymi środkami, a więc przepowiadaniem Słowa Bożego, katechezą a zwlaszcza świadectwem życia i posługiss. Obowiązek troski o powołania należy zatem do istoty posłannictwa kapłańskiego, przez które każdy duchowny uczestniczy w trosce całej

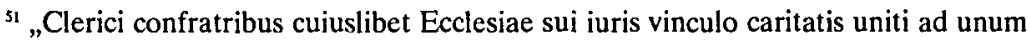
omnes conspirent, ad aedificationem nempe Corporis Christi, et proinde, cuiuscumque sunt condicionis, etsi diversis officiis fungentes, inter se cooperentur seque invicem adiuvent". Kan. 379 KKKW; Por. Sobór Watykański II, Dekret o posłudze i życiu kaplanów Presbyterorum ordinis, nr 8.

${ }^{32}$ Por. Kan. 275 \& 1 KPK; Por. Kaplan - Sluga Zbawienia, w: Synod Archidiecezji Wrocławskiej 1985-1991, Wrocław 1995, s. 144-160.

${ }^{s 3}$ Sobór Watykański II, Dekret o posłudze i życiu kaplanów Presbyteronum ordinis, nr 8.

${ }^{34}$ Tamże.

ss "Sollicitudinem habeant clerici omnes vocationes ad ministeria sacra et ad institutis vitae consecratae ducendam promovendi non solum praedicatione, catechesi aliisve opportunis mediis, sed imprimis vitae ac ministerii testimonio". Kan. $380 \mathrm{KKKW}$; Por. Sobór Watykański II, Dekret o posłudze i życiu kaplanów Presbyterorum ordinis, nr 11. 
eklezjalnej wspólnoty, aby nigdy na ziemi nie zabrakło ewangelicznych robotników pośród Ludu Bożego. Dlatego tak ważne jest, aby Kościól nieustannie posiadal kaplanów potrzebnych do wypełnienia jego zbawczej misji w świecie. Autentyczna troska o powołania kapłańskie i zakonne to złożenie przez duchownego Chrystusowi najwyższego dowodu milościst.

\section{Postawa milości czynnej i uszanowanie roli świeckich}

Prawodawca KKKW zalecił wszystkim duchownym Katolickich Kościołów Wschodnich apostolską gorliwość w okazywaniu miłosierdzia i chrześcijańskiej gościnności, szczególnie wobec osób chorych, udręczonych, prześladowanych, wypędzonych i uciekinierów ${ }^{57}$. Powyższa norma ma swoje źródło w zaleceniach soborowych, które zrodzily się wprost z inspiracji biblijnych ${ }^{58}$, które wprost zobowiązują chrześcijan do świadczenia bliźnim miłości czynnej. W składaniu tego świadectwa duchowni powinni przewodzić, jako płonący duchem apostolskim i będący dla wszystkich przykładem ${ }^{59}$. Apostolska gorliwość nie została przez prawodawcę ograniczona wyłącznie do realizowania tzw. działalności dobroczynno-charytatywnej wobec osób potrzebujących. Dlatego prawodawca określił także, iż duchowni mają obowiązek udzielania wiernym świeckim $z$ duchowych dóbr Kościoła, zwłaszcza w postaci głoszenia Słowa Bożego i sprawowania sakramentów dla tych chrześcijan, którzy o to proszą, znajdują się w należytej dyspozycji duchowej i nie są związani prawną przeszkodą do przyjmowania sakramentów $w^{6}$. Prawodawcy zależy bo-

${ }^{56}$ Por. Tamże.

${ }^{57}$ "Zelo apostolico ardentes clerici omnibus exemplo sint in beneficentia et hospitalitate praesertim erga aegrotantes, afflictos, persecutionem patientes, exiliatos et profugos". Kan. 381 § 1 KKKW; Por. Віктор Д. Поспішіл, Східне Католицьке Церковне право. Згідно з Кодексом Канонів Східних Церков, s. 187; Por. Sobór Watykański II, Dekret o posłudze i życiu kapłanów Presbyteronum ordinis, nr 8.

${ }^{58}$ „Kierując się duchem braterstwa, niech prezbiterzy nie zapominają o gościnności (Hbr 13,1-2), niech praktykują dobroczynność i dzielenie się dobrami (Hbr 13,16), troszcząc się przede wszystkim o chorych, strapionych, obciążonych nadmierną pracą, samotnych, wygnanych z ojczyzny, jak również cierpiących prześladowanie (Mt 5,10)”. Tamże.

${ }^{s}$ Kan. 381 \& $1 \mathrm{KKKW}$.

¿o "Obligatione tenentur clerici, nisi iusto impedimento sunt detenti, suppeditandi ex spiritualibus Ecclesiae bonis verbi Dei praesertim et sacramentorum adiumenta christifidelibus, qui opportune petunt, rite sunt dispositi nec iure a sacramentis suscipiendis prohibentur". Kan. $381 \S 2$ KKKW; Por. Sobór Watykański II, Konstytucja dogmatyczna o Kościele „Lumen gentium”, nr 37. 
wiem na wypracowaniu pełniejszej gorliwości o zbawienie dusz, często wykraczającej poza wyłączne potrzeby wiernych Katolickich Kościołów Wschodnich i Kościoła Łacińskiego.

Specjalną kodeksową formą realizacji obowiązku uszanowania świeckich w KKKW jest powinność duchownych Katolickich Kościołów Wschodnich uznawania i doceniania godności świeckich, obiektywne uznanie ich własnego udziału w misji wspólnoty Kościoła, zwłaszcza różnorakich charyzmatów osób świeckich, ich kompetencji i doświadczenia, $z$ zaangażowaniem wykorzystując je dla dobra samego Kościoła, zawsze w sposób przewidziany prawem $^{61}$. Duchowni podejmując zatem duszpasterskie zaangażowanie we wspólnocie danego kościoła partykularnego powinni być świadomi tego, że Kościół nakłada na nich soborowy obowiązek współpracy ze świeckimi. Stąd nie mogą już tworzyć hermetycznie zamkniętej społeczności, skoro prawo kodeksowe nakłada na nich obowiązek uznania i popierania misji, jaką świeccy, zgodnie ze swoją pozycją, wykonują w Katolickich Kościolach Wschodnich i Kościele Łacińskim, stawszy się uczestnikami funkcji kaplańskiej, prorockiej i królewskiej Chrystusa ${ }^{62}$. Dlatego na wielu płaszczyznach duchowni winni współpracować ze świeckimi, z wrażliwością wsłuchiwać się $\mathrm{w}$ ich głos, uznajac ich doświadczenie $i$ kompetencję $w$ różnych dziedzinach ludzkiego dziatania ${ }^{63}$. Wspólpraca ze świeckimi stanowi istotny wymiar budowania jedności pasterskiej w Ludzie Bożym. Tak więc realizując obowiązek uszanowania i popierania godności świeckich należy z akceptacją odnieść się do soborowej pozycji świeckich we wspólnocie eklezjalnej, w której wymownie rozszerzono zakres współpracy świeckich w ministerialnym posługiwaniu Kościoła ${ }^{64}$.

${ }^{61}$ „Clerici laicorum dignitatem atque propriam partem, quam in missione Ecclesiae habent, agnoscant et promoveant praesertim charismata laicorum multiformia probantes necnon competentiam et experientiam eorum in bonum Ecclesiae vertentes speciatim modis iure paevisis". Kan. $381 \S 3 \mathrm{KKKW}$; Por. Sobór Watykański II, Dekret o apostolstwie świeckich „Apostolicam actuositatem", nr 25.

${ }^{62}$ Por. Kan. 275 \& 2 KPK; Sobór Watykański II, Dekret o apostolstwie świeckich "Apostolicam actuositatem", nr 2; Por. Tamże, Konstytucja dogmatyczna o Kościele „Lumen gentium”, nr 31. nr 9.

${ }^{63}$ Sobór Watykański II, Dekret o posłudze i życiu kapłanów Presbyteronum ordinis,

${ }^{64}$ Рог.Віктор Д. Поспішіл, Східне Католичьке Церковне право. Зеідно з Кодексом Канонів Східни Церков, s. 187. 


\section{Obowiązek powstrzymania się osób duchownych od niestosownych czynności i urzędów}

Normy KKKW zdecydowanie postanawiają, że duchowni Katolickich Kościolów Wschodnich powinni powstrzymywać się od wszystkiego, co nie przystoi ich stanowi, a co obligatoryjnie powinny określić przepisy prawa partykularnego, jak również powinni unikać tego, co jest obce stanowi duchownemu ${ }^{65}$. Zgodnie $\mathrm{z}$ prawem partykularnym niektórych Katolickich Kościołów Wschodnich duchowym zabrania się np. udziału w wyścigach konnych czy też wyjścia do te$a^{a t r u}{ }^{66}$. Należy zauważyć, że powyższa norma prawna jest niemal identyczna jak w KPK Kościoła Łacińskiego, co pozwala głębiej skomentować treść prezentowanego kanonu $382 \mathrm{KKKW}$.

Otóż przykazania Dekalogu i nauka Ewangelii określają istotę godnego życia każdego chrześcijanina. $Z$ nauki Kościoła Powszechnego i praktyki życia wynika, iż nie wszystko co przystoi ludziom świeckim jest dobrze przyjmowane w odniesieniu do osób duchownych. Dlatego prawo kodeksowe Jana Pawła II zobowiązuje duchownych do powstrzymania się od tego wszystkiego, co nie przystoi ich stanowi, a co szczegółowo powinny określić przepisy prawa partykularnego ${ }^{67}$. Prawodawca wydając taką normę zawsze stoi na straży zachowania godności stanu duchownego, jak również pragnie wykluczyć to wszystko, co może spowodować zgorszenie, zdziwienie lub nawet ośmieszenie stanu duchownego w środowisku wiernych świeckich. Zatem osoby duchowne wszystkich obrządków katolickich powinny unikać czynności i zajęć, które nie stanowią o istocie stanu duchownego, choć te czynności same z siebie nie są nieprzyzwoite ${ }^{68}$. Prawodawca może wskazać nawet na profesje dobre, potrzebne i słuszne, lecz na pewno do ich wykonywania nie potrzeba święceń kapłańskich np. nie ma potrzeby, by duchowny musiał zarabiać jako taksówkarz, członek zespołu muzycznego, lekarz, czy też menadżer ${ }^{69}$. Należy uzupełnić, iż źródłem szczegółowych

\footnotetext{
${ }^{65}$ "Abstineant prorsus clerici ab eis omnibus, quae statum eorum secundum normas iure particulari pressius determinatas dedecent, et etiam evitent ea, quae ab eo aliena sunt". Kan. 382 KKKW.

${ }^{66}$ Por. Віктор Д. Поспішіл, Східне Католичьке Церковне право. Заідно з Кодексом Канонів Східних Церков, s. 187.

${ }^{67}$ Por. Kan. $285 \S 1$ KPK.

${ }^{6}$ Por. Kan. 285 \& 2 KPK.

${ }^{69}$ Por. T. Pawluk, Prawo kanoniczne wedlug Kodeksu Jana Pawla II, t. IV, s. 98.
} 
norm prawa partykularnego w tej kwestii staje się również tradycja Katolickich Kościołów Wschodnich wyrażona m.in. w Kanonach Apostolskich ${ }^{70}$.

Prawodawca następnie zadeklarowal, iż duchowni Katolickich Kościołów Wschodnich powinni posiadać prawa cywilne i polityczne na równi $\mathrm{z}$ innymi obywatelami, to jednak zabrania się im przyjmowania urzędów publicznych, które pociągają za sobą uczestniczenie w wykonywaniu władzy publicznej" ${ }^{\text {" }}$ Taka sama norma obowiązuje duchownych łacińskich, dlatego również im kanonicznie zabrania się przyjmowania publicznych urzędów, z którymi jest złączona konieczność uczestniczenia w wykonywaniu władzy świeckiej ${ }^{72}$. Przyjęcie takich świeckich urzędów nie jest do pogodzenia $\mathrm{z}$ posługą sakramentalną, a konflikt porządku zewnętrznego $z$ wewnętrznym mógłby być nieunikniony ${ }^{73}$. Konsekwencją takiego stanowiska Kościoła Łacińskiego jest następna norma kodeksowa KPK, w której stwierdza się, że duchowny może zarządzać dobrami i urzędami należącymi do świeckich, z którymi łączy się obowiązek prowadzenia rachunków, tylko za zgodą swego ordynariusza.

Kodeks Kanonów Kościołów Wschodnich obligatoryjnie stwierdza, że służba wojskowa nie odpowiada stanowi duchownemu, stąd duchowni nie mogą dobrowolnie zaciągać się do wojska, chyba że uzyskają zgodę swego Hierarchy ${ }^{74}$. Identyczną dyscyplinę w tej kwestii wyznacza Kodeks Prawa Kanonicznego z 1983 r. określając odbywanie służby wojskowej przez duchownych jako czynność niestosowną ${ }^{75}$. Dlatego duchowni nie powinni się dobrowolnie zaciągać do służby wojskowej, chyba że zgodę wyrazi ordynariusz własny. Obecnie pelnienie służby wojskowej jest szczegółowo określone na podstawie porozumienia wladzy świeckiej z kościelną, jak również

${ }^{70}$ Por. Les canons des synodes particuliers, wyd. P. -P. Joannou, Pontificia commissione per la redazione del codice di diritto canonico orientale. Fonti, Fasc. IX, t. I/2, Grottaferrata - Roma 1962, 30; Por. Dokumenty Soborów Powszechnych. Tekst grecki, laciński, polski. T. I, opr. Ks. Arkadiusz Baron - ks. Henryk Pietras, Kraków 2001, s. $42 \mathrm{nn}$.

${ }^{71}$ Kan. 383 nr 1 KKKW.

${ }^{72}$ Por. Kan. 285 § 3 KPK.

${ }^{73}$ Por. G. Ghirlanda, Wprowadzenie do prawa koscielnego, s. 72-74.

${ }^{74}$ Por. Kan. 383 nr 2 KKKW.

${ }^{75}$ Por. Kan. $289 \S 1$ KPK. 
została uregulowana prawnie obecność duchownych w strukturach wojskowych ${ }^{76}$.

Duchowni Katolickich Kościolów Wschodnich powinni obowiązkowo korzystać ze zwolnień od wykonywania zadań i urzędów publicznych obcych stanowi duchownemu, jak też ze służby wojskowej, przyznanych na ich korzyść przez ustawy państwowe albo umowy i zwyczaje ${ }^{77}$. W kodeksie lacińskim znajdują się podobne normy zabezpieczające uprawnienia duchownych, z których jednak należy korzystać $w$ poczuciu pełnienia obowiązku słusznego wobec stanu duchownego. Dlatego duchowni powinni korzystać ze zwolnień od wykonywania zadań i publicznych obowiązków cywilnych, które są obce stanowi duchownemu, powołaniu kapłańskiemu, przyznanych na ich korzyść przez ustawy, umowy lub zwyczaje, chyba, że ordynariusz zarządził inaczej ${ }^{78}$. Motywem i inspiracją do takiej normy jest słuszne przekonanie, że również duchowni katolickich obrządków pracują publicznie i dla dobra powszechnego, a ich posłannictwo jest ściśle związane ze służbą człowiekowi i konkretnej wspólnocie państwowej ${ }^{79}$.

Kościół przyznaje wszystkim duchownym prawo do korzystania $\mathrm{z}$ praw cywilnych i politycznych na równi z innymi obywatelami, jednak wyraźnie zabrania im piastowania urzędów publicznych, związanych ze sprawowaniem władzy publicznej i zaciągania się do służby wojskowej bez zgody Hierarchy. Zaleca również korzystanie $\mathrm{z}$ prawa zwalniającego duchownych $\mathrm{z}$ wykonywania publicznych zadań i urzędów, przynajmniej w niektórych kra$\mathrm{jach}^{80}$.

${ }^{76}$ Por. Jan Pawel II, Konstytucja Apostolska Spirituali Militium Curae na temat ordynariatów polowych, w: Schematyzm Ordynariatu Wojska Polskiego 1995, Warszawa 1995, s. 237-242; Instrukcja Biskupa Polowego o strukturze duszpasterskiej Ordynariatu Polowego Wojska Polskiego z dnia 7 grudnia 1992 r., w: Schematyzm Ordynariatu Polowego Wojska Polskiego 1994, s. 73-83.

${ }^{n}$ Por. Kan. 383 nr 3 KKKW.

${ }^{78}$ Por. Kan. 289 \& 2 KPK. Kodeks z 1917 r. za takie czynności uważal zajęcia medyczne, stanowisko publicznych notariuszy, świeckiego sądownictwa, udział w rządach, piastowanie urzędów, z którymi związana była odpowiedzialność finansowa, piastowanie urzędów i funkcji adwokatów w sądach świeckich. Por. Kan. 137 KPK.

${ }^{7}$ „Duchowni będą zwolnieni z obowiązków obywatelskich niezgodnych z powołaniem kaplańskim, jako to: sędziów przysięglych, czlonków trybunałów...”. Por. Konkordat między Polską a Stolicą Apostolską z 1925 r., art. V.

${ }^{30}$ Рог. Віктор Д. Поспішіл, Східне Католицьке Церковне право. Згідно з Кодексом Канонів Схадних Церков, s. 187. 


\section{Obowiązek wspierania pokoju, jedności i zgody}

KKKW wymownie nazywa duchownych Katolickich Kościołów Wschodnich sługami pojednania wszystkich ludzi w miłości Chrystusa. Dlatego powinni troszczyć się oni o wspieranie pokoju wśród ludzi, jak również jedności i zgody opartej na sprawiedliwości" ${ }^{81}$ Równiez w KPK prawodawca kościelny zobowiązuje duchownych, aby w realizacji swego posługiwania jak najbardziej popierali zachowanie między ludźmi pokoju i zgody, opartej na zasadzie sprawiedliwości ${ }^{82}$. Inspiracją religijną dla duchownych wszystkich obrządków katolickich staje się wezwanie do przyjęcia Chrystusowego pokoju, jak również niezbędną jest wola poszanowania godności wszystkich ludzi oraz ich podstawowych praw, co zdecydowanie wpływa na budowanie autentycznego braterstwa ${ }^{83}$. Najgłębsze przekonanie motywujące do zachowania pokoju ze wszystkimi rodzi się z wewnętrznej jedności duchownego z samym Chrystusem ${ }^{84}$.

Okolicznością wymownie sprzyjającą wspieranie pokoju, jedności i zgody staje się codzienne posługiwanie i inna działalność duchownego. Dlatego prawodawca w KKKW obligatoryjnie stwierdził, iz duchowni Katolickich Kościołów Wschodnich nie mogą brać udziału w działalności partii politycznych, ani w kierowaniu związkami zawodowymi, chyba że według osądu biskupa eparchialnego lub jeśli tak stanowi prawo partykularne wydane przez $\mathrm{Pa}$ triarchę albo inną władzę, wymaga tego obrona praw Kościoła albo rozwój dobra wspólnego ${ }^{85}$. Wynika $z$ tego, że prawodawca realnie postrzega okoliczności, w których duchowni mogą być członkami ugrupowań politycznych, jednakże nie powinni aktywnie uczestniczyć w ich działalności, jak również w działalności związków zawodowych, które w jakiejś mierze włączają się w nurt zmagań a nawet

\footnotetext{
8t „Ministri reconciliationis omnium in Christi caritate satagant clerici pacem, unitatem et concordiam iustitia innixam inter homines fovere". Kan. $384 \S 1$ KKKW.

${ }^{82}$ Por. Kan. $287 \S 1$ KPK.

${ }^{83}$ Por. Sobór Watykański II, Konstytucja duszpasterska o Kościele w świecie współczesnym Gaudium et spes z dnia 7 grudnia 1965 r., nr 78.

${ }^{84}$ Por. Tamże, nr 92.

${ }^{85}$ „In factionibus politicis atque in moderandis consociationibus syndicalibus activam partem ne habeant, nisi iudicio Episcopi eparchialis vel iure particulari ita ferente Patriarchae aut alterius auctoritatis iura Ecclesiae tuenda aut bonum commune promovendum id requirunt". Kan. $384 \S 2$ KKKW.
} 
konfliktów politycznych ${ }^{86}$. Jednakże ostatnie słowo należy w tej materii do prawa partykularnego wydanego przez Patriarchę lub inną władzę, zwłaszcza kiedy wymaga tego troska o uszanowanie praw Kościoła lub właściwy i pełny rozwój dobra wspólnego.

Należy jednak w tym miejscu zauważyć, że normy prawne Kościoła Łacińskiego zdecydowanie stwierdzają, iż czynne zaangażowanie się duchownego w działalność partii politycznych i związków zawodowych jest czynnością niestosowną. KPK wskazal jednak, że taką czynnością przestaje być w przypadku kiedy obecność duchownego w takich okolicznościach jest konieczna, ze względu na obronę praw Kościoła lub rozwój dobra wspólnego ${ }^{87}$. Jednak o tym nie decyduje osobiście duchowny lecz jego przełożony, od którego otrzymuje stosowną misję do spełnienia.

Obowiązek wspierania pokoju, jedności i zgody przez duchownego prawodawca postrzega również $\mathrm{w}$ kategoriach osobistego świadectwa życia. Stąd w normach KKKW znalazło się wymaganie, aby unikali jakichkolwiek waśni między sobą i z innymi chrześcijanami. Jeśli zaś taki spór powstanie między duchownymi to należy go rozstrzygnąć wyłącznie na forum Kościoła oraz w taki sposób należy postąpić, kiedy stronami sporu stają się duchowni i inni chrześcijanie ${ }^{88}$. Prawodawcy zależy więc na tym, aby sprawy konfliktowe duchownych i wiernych świeckich byly w miarę możliwości rozstrzygane przez sądy kościelne czy też postępowanie i decyzje pozasądowe ${ }^{89}$.

\section{Obowiązek świadectwa przez proste i skromne życie}

Kodeksowa motywacja dla realizacji przez duchownych obowiązku składania życiowego świadectwa zasadza się mocno na inpiracjach biblijnych, a zwłaszcza na fundamencie ubóstwa Jezusa Chrystusa. Stąd prawodawca postanowił, ze duchowni natchnieni duchem ubóstwa Chrystusowego powinni starać się przez prostotę ży-

\footnotetext{
${ }^{86}$ Рог. Віктор Д. Поспішіл, Східне Католицьке Церковне право. Заідно з Кодексом Канонів Східних Церков, s. 187.

${ }^{87}$ Por. Kan. 287 \& 2 KPK.

${ }^{88}$ „Clerici quaslibet contentiones evitare studeant; si tamen quaedam contentio exsurrexit inter eos, ad forum Ecclesiae deferatur et hoc, si fieri potest, etiam fiat, si de contentionibus inter clericos et alios christifideles agitur". Kan. $389 \mathrm{KKKW}$; Por. Can. $120 \S 1 \mathrm{CIC} / 1917$.

${ }^{89}$ Рог. Віктор Д. Поспішіл, Східне Католицьке Церковне право. Заідно з Кодексом Канонів Східних Церков, s. 188.
} 
cia być dla świata świadkami dóbr najwyższych, a dobra doczesne przeznaczać według prawego duchowego rozeznania. Natomiast dobra nabyte $z$ racji wykonywania urzędu, posługi lub kościelnego zadania powinny posłużyć im na zabezpieczenie stosownego utrzymania, realizację obowiązków swego stanu, jak również powinny być przeznaczone na dzieła apostolstwa lub miłości ${ }^{90}$. Wynika stąd, że duchowni Katolickich Kościołów Wschodnich powinni pragnąć prostego stylu życia, który jednak nie pozbawia ich samych i rodzin odpowiedniego bytu materialnego, jak również pozwala dysponować słusznymi środkami na dzieła miłosierdzia ${ }^{11}$. Podobne obligacje prawne dotyczą również duchownych Kościoła Łacińskiego, bowiem prawodawcy słusznie zależy na tym, by współcześni duchowni prowadzili życie proste i wystrzegali się wszystkiego, co może być oznaką lub faktyczną próżnością 92 . Dlatego diakoni, kapłani i biskupi nie powinni upodobniać się do ludzi świeckich, zwłaszcza w dążeniu do wyszukanego komfortu życia. Stąd w ich codzienności przeciwną chrześcijańskiej prostocie i skromności będzie wystawność życia. Natomiast źródłem dla zachowania postawy skromności winno być przesłanie Objawienia Bożego, które zwraca uwagę duchownych na fakt, że osoby gloszące Ewangelię, chociaż żyją w świecie, to jednak nie są $\mathrm{z}$ tego świata ${ }^{93}$. Skromność życia ma również w Kościele Łacińskim pełną wartość ewangelicznego świadectwa, dlatego duchowni winni należycie dbać o dobra materialne, swój wygląd, styl życia, lecz nie powinni ulegać modzie na posiadanie rzeczy najlepszych i najdroższych, co może stać się elementem publicznego zgorszenia i oskarżenia wysuwanego wobec całego Kościoła.

Także w zakresie dysponowania dobrami nabytymi prawo kodeksowe Kościoła Łacińskiego zobowiązuje swoich duchownych, nie na zasadzie ścisłego obowiązku lecz kanonicznego zalecenia, aby część dóbr materialnych, które im przypadły $z$ racji wykonywania urzędu kościelnego, dobrowolnie i chętnie przekazali na pomnożenie dobra Kościoła i wsparcie dzieł miłości, a więc dzieł charytatywnych. W nauce prawa mówi się o tzw. dobrach zbywających, co

\footnotetext{
${ }^{90}$ Por. Kan. $385 \$ 1$ KKKW.

"1 Por. Віктор Д. Поспішіл, Східне Католичьке Церковне право. Заідно з Кодексом Канонів Східних Церков, s. 187.

${ }^{92}$ Por. Kan. $282 \& 1 \mathrm{KPK}$.

${ }^{93}$ Por. J 17,14-16; 1 Kor 7,31.
} 
oznacza, że duchowny najpierw ze swoich dochodów powinien zapewnić sobie godziwe utrzymanie i zadbać o środki na należyte wypełnienie szczegółowych obowiązków stanu, a resztę uposażenia szczodrobliwie przeznaczyć na wymienione wyżej cele ${ }^{94}$. Podstawą i motywem do przekazania tych dóbr powinna być nie tyle cnota sprawiedliwości, lecz chrześcijańska układność, osobista wraźliwość i niekłamana pobożnośćcs.

Dla jasności należy przypomnieć, że bona superflua to takie, które pozostają do dyspozycji duchownego po zabezpieczeniu godziwego utrzymania i swojej działalności. Nie tworzą ich środki materialne, które duchowny posiadł w innych okolicznościach życia, niż wykonywanie urzędu kościelnego. Klasycznym przykładem mogą być dobra odziedziczone lub otrzymane przez imienną darowiznę. Również należy wskazać, iż godziwe utrzymanie obejmuje codzienne lub okresowe wydatki świadczone przez duchownego na wyżywienie, mieszkanie, ubranie, wynagrodzenie dla osób, które wykonują u niego prace domowe, fundusze na sprawy kultury i wypoczynku, leczenie, zapewnienie warunków gościnności i godnego przyjęcia innych osób, jak również konieczna pomoc dla najbliższych np. rodziców wymagających opieki. Natomiast zabezpieczenie swojej działalności obejmuje wydatki związane z zakupem pomocy naukowych i duszpasterskich, płacenie podatków, pokrywanie oplat związanych z kursami i zjazdami duszpasterskimi i teologicznymi, permanentne dokształcanie się. W świadczeniu pomocy materialnej, której źródłem są dobra zbywające należy uszanować zalecenie Kościoła, by środki te przeznaczać nie na cele filantropijne, lecz na cele kościelne, a więc jako wsparcie dla dzieł prowadzonych przez Kościół np. budowa świątyni, utrzymanie seminarium, dzieła misyjne lub dzieła milości ${ }^{96}$.

W ramach realizacji kodeksowego obowiązku świadectwa przez proste i skromne życie prawodawca zabrania duchownym Katolickich Kościołów Wschodnich uprawiania handlu oraz dokonywania osobiście lub przez pośrednictwo innych osób wszelkich transakcji, czy to na korzyść wlasną czy też innych, chyba że na takie działanie wyrazi

\footnotetext{
${ }^{94}$ Por. Kan. $282 \& 2$ KPK

${ }^{95}$ Por. T. Pawluk, Prawo kanoniczne wedlug Kodeksu Jana Pawla II, t. IV, s. 95.

${ }^{96}$ Por. Sobór Watykański II, Dekret o posludze i życiu kaplanów Presbyterorum ordinis, nr 17.
} 
zgodę władza wskazana przez prawo partykularne Kościoła sui iuris albo odpowiednia decyzja Stolicy Apostolskiej" . Zabrania się również duchownym poręczania nawet własnym majątkiem, chyba że po konsultacji z własnym biskupem eparchialnym lub jeśli trzeba, z przełożonym wyższym ${ }^{98}$. Również w Kościele Łacińskim nie wolno osobie duchownej poręczać, nawet własnym majątkiem, bez porozumienia ze swoim przełożonym i podpisywać weksli obligujących do wypłacania środków materialnych ${ }^{99}$. Restrykcje kanoniczne odnoszą się także do zakazu uprawiania handlu i dokonywania transakcji, zarówno osobiście przez duchownych lub ich przedstawicieli, chyba, że czynią to za akceptacją legalnej władzy kościelnej ${ }^{100}$. Tak więc duchowny nie może się angażować $\mathrm{w}$ transakcje handlowe podejmowane dla materialnego zysku, bowiem podjęcie takiej działalności jest obwarowane sankcją karną, wymierzoną przez przełożonego stosownie do cięźkości przestępstwa ${ }^{101}$. Prawodawcy wymownie zależy na tym, aby styl życia duchownych wszystkich obrządków katolickich był prosty i skromny, a więc spełniał wymogi ewangelicznego świadectwa.

\section{Obowiązek przebywania w swojej eparchii}

Dyscyplina prawna KKKW określa również sprawę obowiązku przebywania swych duchownych w kościele partykularnym. Dlatego duchowni, chociażby nie piastowali urzędu rezydencjalnego, nie powinni na dłuższy czas, który należy określić w prawie partykularnym, opuszczać swojej eparchii bez pozwolenia - przynajmniej domniemanego - własnego Hierarchy miejsca. Natomiast jeśli przebywa poza własną eparchią podlega kanonicznie biskupowi eparchialnemu miejsca w tym, co dotyczy obowiązków stanu duchownego. Jeśli zamierza przebywać w tym miejscu dłuższy czas powinien o tym bezzwlocznie powiadomić Hierarchę tego miejsca ${ }^{102}$. Wynika $z$ tego, że duchowny którego aktualne miejsce zamieszkania i przebywania znajduje się w innej eparchii staje się podmiotem zależnym w sprawach obowiązków stanu duchownego od miejscowego Hierarchy, z którym powinien podjąć układne relacje i powiadomić go o woli przebywania na

\footnotetext{
${ }^{97}$ Por. Kan. 385 § 2 KKKW.

${ }^{98}$ Por. Kan. $385 \$ 3$ KKKW.

${ }^{9}$ Por. Kan. $285 \S 4$ KPK.

${ }^{100}$ Por. Kan. 286 KPK.

${ }^{101}$ Por. Kan. 1392 KPK.

${ }^{102}$ Por. Kan. $386 \S 1-2$ KKKW.
} 
terenie jego kościoła partykularnego. Dostępne dzisiaj wygodne i szybkie środki transportu sprawiają, że duchowni mogą mieć wiele powodów do przebywania poza granicami własnej eparchii: emerytura, troska o zdrowie, dłuższe odwiedziny, podjęcie studiów itp. Miejscowym hierarchą, z którym duchowny ma obowiązek skontaktowania się jest biskup eparchialny lub inny hierarcha Kościoła sui iuris, także Biskup Diecezjalny łacińskiego kościoła partykularnego ${ }^{103}$.

KPK Kościoła Łacińskiego podobnie określa obowiązek przebywania duchownego w swojej diecezji, ponieważ podstawowym tytułem do święceń tego duchownego była praca w kościele partykularnym. Stąd prawne zobowiązanie, obligujące duchownego do stałego przebywania na terenie swojej diecezji, nawet wtedy, gdyby nie piastował urzędu rezydencjalnego. Nieobecność nie powinna trwać dłuższy czas, natomiast każdorazowe opuszczenie swojej diecezji na dłuższy okres powinno się dokonywać za zgodą ordynariusza ${ }^{104}$. Prawodawca w powyższej materii odsyła do szczegółowych ustaleń, które winny się znaleźć w dokumentach i przepisach prawa partykularnego ${ }^{105}$.

Analizując kodeksowy obowiązek przebywania duchownego Kościoła Lacińskiego w swojej diecezji, należy bliżej określić kanoniczną treść tzw. urzędu rezydencjalnego. Chodzi bowiem o takie kościelne posługiwanie, $\mathrm{z}$ którym jest nierozerwalnie złączony obowiązek przebywania w miejscu, gdzie duchowny winien wypełnić powierzone mu zadanie. Bezpośrednio dotyczy to np. proboszcza, wikariusza parafialnego, urzędników diecezjalnych instytucji. Natomiast urząd nierezydencjalny nie wiąże osoby duchownej koniecznością przebywania w stałym miejscu. Wystarczy bowiem, aby przebywać $\mathrm{w}$ miejscu wskazanym w czasie wypełniania swojej posługi np. profesor seminarium. Należy też dodać, że ogólny obowiązek przebywania w swojej diecezji mają wszyscy piastujący urzędy, z tym jednak, że urzędnicy rezydencjalni muszą przebywać na stałe w miejscu pełnienia urzędu ${ }^{106}$, a nierezydencjalni przynajmniej w granicach swojej diecezji.

\footnotetext{
${ }^{103}$ Рог. Віктор Д. Поспішіл, Східне Католичьке Церковне право. Згідно з Кодексом Канонів Східних Церков, s. 187.

${ }^{104}$ Por. Kan. $283 \& 1$ KPK.

${ }^{105}$ Por. Wewnętrzna organizacja Archidiecezji Wroctawskiej, w: Synod Archidiecezji Wrocławskiej 1985-1991, s. 347-361.

${ }^{106}$ Por. Kan. 533 \& 1 KPK.
} 
Przepisy prawa powszechnego nie określają wiążąco, co znaczy dłuższy czas nieobecności duchownego. Można jednak przyjąć, iż prawodawca miał na myśli taki rodzaj nieobecności, która może dla osoby duchownej stanowić zdecydowaną przeszkodę w rzetelnym i odpowiedzialnym wypełnieniu przyjętych obowiązków, a powierzonych mu przez kościelną władzę, jak również, że stan dłuższej nieobecności może poważnie i skutecznie utrudnić urzędowe relacje duchownego ze swoim przełożonym. By takie sytuacje wykluczyć, albo zminimalizować w skutkach, istnieje zatem formalny zakaz opuszczania diecezji na dłuższy czas i zakaz bezprawnego opuszczenia miejsca sprawowania urzędu. W praktyce Kościoła partykularnego nie ma takiej potrzeby, by duchowny musiał wybierać rozwiązania niestosowne, skoro zawsze jest moźliwa komunikacja $\mathrm{z}$ ordynariuszem i uzyskanie jego kanonicznej zgody w tej kwestii.

\section{Obowiązek troski o rozwój wszystkich Kościołów}

KKKW nakłada na duchownych Katolickich Kościołów Wschodnich obowiązek odpowiedzialnej troski o rozwój wszystkich Kościolów. Dlatego duchowni bez względu na swoją pozycję i piastowaną godność, powinni troszczyć się o wszystkie Kościoły. Autentyczna troska - zdaniem prawodawcy kodeksowego - powinna wyrażać się w gotowości duchownego do spełniania posługi, gdziekolwiek nagli konieczność, a zwłaszcza - za zgodą lub zachętą swego biskupa eparchialnego lub przełożonego - do wykonywania swojej posługi na misjach albo w regionach cierpiących na brak duchownych ${ }^{107}$. Prawodawca uczy zatem dostrzegania potrzeb Kościoła Powszechnego przez służebny wymiar kapłańskiej posługi każdego z duchownych. W normach KPK Kościoła Lacińskiego prawodawca dokładnie określił również okoliczności i możliwości podjęcia pracy przez duchownych pochodzących z innych kościołów partykularnych. Racje i potrzeby duszpasterskie wystarczająco uzasadniają pobyt duchownego poza terenem swojego kościoła partykularnego, co niewątpliwie wymaga formalnej zgody zainteresowanych biskupów ${ }^{108}$.

${ }^{107}$ „Clericis, cuiuscumque sunt condicionis, cordi sit sollicitudo omnium Ecclesiarum et ideo se ad inserviendum, ubicumque urget necessitas, promptos exhibeant et praesertim permittente vel exhortante proprio Episcopo eparchiali vel Superiore ad suum ministerium in missionibus vel regionibus clericorum penuria laborantibus exercendum". Kan. 393 KKKW.

${ }^{108}$ Por. Kan. $271 \S 1$ 1-3 KPK. 
Z norm obydwu kodeksów wynika zatem, że duchowni powinni świadczyć pomoc $w$ posługiwaniu kapłańskim $w$ tych miejscach, gdzie występuje brak wystarczającej liczby duchownych. Biskup eparchialny, biskup diecezjalny oraz także przełożeni zakonni powinni tę pomoc ze wszech miar popierać, o ile pozwalają na to okoliczności miejsca i czasu.

\section{Zakończenie}

Zaprezentowane w artykule obowiązki duchownych Katolickich Kościołów Wschodnich wyraźnie korespondują z powinnościami duchownych Kościoła Łacińskiego. Dzieje się tak dlatego, że rzeczywistość posługiwania kapłańskiego i sama kapłańska tożsamość ma wspólne źródło, którym jest nauka objawiona Słowa Życia oraz Tradycja, tak istotna dla charyzmatu kapłaństwa Katolickich Kościolów Wschodnich. Prezentacja obowiązków obligatoryjnie określonych przez prawodawcę w KKKW stała się pełniejsza przez zastosowanie metody porównawczej, która w wielu punktach umożliwiła konfrontację treści norm kodeksu łacińskiego z kodeksem Kościołów Wschodnich. W artykule poddano refleksji wyłącznie obowiązki wspólne wszystkim duchownym Katolickich Kościołów Wschodnich i paralelne dla duchownych Kościoła Łacińskiego. Należy zauważyć, iż niektóre z obowiązków duchownych rzymskokatolickich stały się w Katolickich Kościołach Wschodnich prawami osób duchownych, dlatego zaistniała konieczność kolejnego opracowania porównawczego w zakresie praw duchownych w promulgowanym Kodeksie Kanonów Kościołów Wschodnich.

\section{De obligationibus clericorum in Codice Canonum Ecclesiarum Orientalium}

Codex Canonum Ecclesiarum Orientalium a Papa Joanne Paulo II Constitutione Apostolica Sacri Canones, die 18. X. 1990 a. promulgatus, complures taxativas obligationes communes omnibus clericis Catholicarum Ecclesiarum Orientalium enumerat. In articolo hoc 12 obligationes indicantur, quae ad obligationes clericorum in eorum pastorali cura in Ecclesia sui iuris referuntur. Maior pars obligationum in CCEO eadem est cum normis CIC propter eundem fontem, quem Revelatio et Traditio Ecclesiae constituit. Tamen in CCEO aliquae differentiae cum CIC inveniuntur, propter diversas solutiones, quae erga clerum Ecclesiae Latinae acceptae sunt. 